\title{
Consumer Ethnocentrism and Willingness to Buy: Analyzing the Role of Three Demographic Factors in Karachi
}

\author{
Rajkumar Lohano \\ IQRA University, Karachi \\ Shuaib Ahmed \\ Institute of Business \& Technology, Karachi \\ Badar Zaman Qureshi \\ IQRA University, Karachi \\ Furqan-Ul-Haq Siddiqui \\ Institute of Management Sciences, University of Balochistan, Quetta.
}

\begin{abstract}
Purpose: This Research study was conducted to empirically explore that the ethnocentrism and willingness to buy associated with three demographic factors prevalent in Karachi Pakistan.

Methodology/Sampling: The data comprised 250 respondents being urban, educated and belong to the different organizations operating in Karachi. The data was collected through structured and self administered questionnaire. Independent t test and simple linear regression were used to test the hypotheses.

Findings: Results showed that aged male $\&$ female and low income groups are more ethnocentric and willing to buy locally made product as compared to young, high income groups. Findings of simple linear regression showed that all the variables statistics are significant at .05 level. This significance showing that there is significant and positive impact of consumer ethnocentrism on willingness to buy.

Practical Implications: The research provides an insight into consumer behavior in Pakistan enabling local and multinational organization for long term strategy development \& implementation as per this study.
\end{abstract}

Keywords: Consumer ethnocentrism, Willingness to buy, Karachi.

\section{JEL Classification: M300, M310}

\footnotetext{
* The material presented by the authors does not necessarily portray the viewpoint of the editors and the management of the Institute of Business \& Technology (IBT).

* Rajkumar Lohano: rajkumar1986@hotmail.com

* Shuaib Ahmed: Shoaib.ahmed@ibt.edu.pk

* Badar Zaman Qureshi: badarzamanqureshi@gmail.com

* Furqan-ul-Siddiqui: furqan.ul.haq@gmail.com

CJMSS is published by the Institute of Business and Technology (IBT). Main Ibrahim Hydri Road, Korangi Creek, Karachi-75190, Pakistan.
} 


\section{INTRODUCTION}

In international markets globalization provides substantial challenges and opportunities. The consumer has more foreign product choices due to relaxation of trade policies than ever before. Accordingly, for a decade researcher attitude towards product development from other countries have been the interest of consumer behavior and international business. Due to the globalization, there is excess of foreign arrivals in Karachi. The young generations moving towards these brands, mostly they are willing to buy the foreign brands because they feel that it is the sign of status. According to the (Sumner, 1806) ethnocentrism was initially used to view things where customers take everything in connection with their center point. (Porter,1990) studied that the modern era of competition every firm interested to securing their position in the domestic markets, if the firm succeed in the domestic market it has chance to have success abroad. According to (Cleveland, Laroche \& Papadopoulos, 2009; Shankarmahesh, 2006; Chao, 2005; Kaynak \& Kara, 2002) that the relation between domestic firms and their domestic consumers has been the object of both academic worlds and business.

According to the (Cooil, 2007; Crask and Reynolds, 1978; Fisher and Dube, 2005; Lambert, Laurant \& Lapersonne, 2005; Meyers-Levy \& Maheswaran, 1991) at that time the academic research has revealed important differences among behavior of demographic factors and consumers' cognitive processes. (Shimp \& Sharma, 1987) examined the trend about ethnocentric related to values about the correctness and consistency while purchasing brands. (Klein, Ettenson \& Morris, 1998) studied that patriotic consumers favor home country products because they believe that the home country products are the best. The arguments which have been discussed in literature are to be tested scientifically. Further provide practical facts about the role of demographics in consumer ethnocentrism on willingness to buy and the relationship between demographic factor and the relationship with consumer ethnocentrism on willingness to buy.

\subsection{Problem Statement}

Now a days trade policy is keen issue for countries. All over the world goods are spreading across boundaries. Free trade policy and globalization is common so therefore there is excess of foreign goods in the local market. In Pakistan many goods manufactured locally. People have choice to opt any foreign brands or the local brands. While purchasing any local brand, ethnocentrism is a factor which has direct influence over their purchasing behavior. This ethnocentrism can influence the consumers to buy the local brand. This research caters that what is the role of ethnocentrism during purchasing any brand and is this factor varies among demographic factors.

\section{LITERATURE REVIEW}

\subsection{Consumer Ethnocentrism}

According to (Sumner, 1906) general notion of ethnocentrism has been discussed 80 years ago. Ethnocentrism according to sociologist are the perception towards entity which differs between in-groups (belongs to own country) and out groups (belongs to foreign). Levine, Robert, 
\& Donald, Campbell, (1972) examined ethnocentrism in relation with personality traits and culture. He explained the relationship that the beliefs play a vital role while purchasing entity and more appropriate while purchasing foreign brand. How beliefs play a role while purchasing brand which do not possess the characteristics according to your value.

The patriotic consumers are in view that consuming foreign brands are not appropriate when domestic products are available in market. Why not promote our own economy which leads to increase number of jobs and boost our industry. The consumers who hold such point are known as ethnocentric. The consumers who are less ethnocentric in view that foreign products hold advantages over domestic products e.g. quality, design and they evaluate such products according to their merits of products. The foreign products manufactured in line with quality control system therefore it gives more durability, comfort and long lasting effect. Consumer ethnocentrism holds characteristics like sense of identity, feeling of associations and ethnocentric purchase behavior. Nationalism is the factor which creates the elements of ethnocentrism. Worchel, Stephen \& Cooper (1979) examined that in general the word ethnocentrism holds the liking of products which has manufactured in own country and they associate with their own people. Further, they disassociate them from those who are culturally different and rejects their products despite having beneficial characteristics. They just associate it with own people.

The lifestyle, symbols, rituals and values of own people are in center of attention and do not attach with products who do not have posses such characteristics. Baughn \& Yaprak, (1996) explain this phenomenon as comparison between groups (in \& out) which bifurcate as domestic and internationals companies. The ethnocentrism has been studied as product of own country and hold national dimensions. Keillor \& Hult, (1999) conduct research of high order of identity which consists of dimension, heritage, culture equalities, value and belief system and ethnocentrism. They gathered data from different countries and substantiate that all dimensions of national identity reflect discrimination against foreign products. Baughn \& Yaprak, (1996) further explained that this phenomenon is due to domestic preferences which in turn show the behavior of discrimination against all foreign products (Klein, Ettenson \& Morris, 1998) discussed consumer animosity and explained that consumer negatively associate their feelings towards country due to war, economics of political affairs etc.

Cannon \& Yaprak, (2002) explained that multi ethnic consumers are unaffected by their home culture and try to involve their selves in culture in which they are living. Hannerz, (1990) argues that multi ethnic consumers try to gain association with new culture and take active part to belong it. Thompson \& Tambyah (1999) argues that individuals are willing to become more multi ethnic to gain more prestige in society. Steenkamp, Hofstede, \& Wedel (1999) also supported and explained it as global culture. (Cannon \& Yaprak, 2002) argued that multi ethnic consumers do not necessary actively associate to new culture but just follow the life style of such culture. Cleveland, Laroche, \& Papadopoulos (2009) substantiate that impact of multi ethnic on consumer behavior are differ across cultures.

Research shows that it is not necessary that all consumers are equally ethnocentric. Shimp \& Sharma, (1987) found that individual who are more ethnocentric are not familiar with culture. Balabanis, Mueller, \& Melewar, (2002) found that consumer who are more patriotic are more conservative. Sharma, Shimp \& Shin (1995) found that consumers who are more patriotic have more collective approach, are more materialistic. Olsen, Granzin \& Biswas, (1993) found that 
consumers who are more patriotic are more rigid. Anderson \& Cunningham (1972) found that who are more patriotic are less educated.

\subsection{Willingness to Buy}

Willingness to buy has been described the attention or perception towards product and services and either person is willing to purchase product or brand. The same notion has been studied with products in relation to the country of origin. The consumer's choice for product depends on country of origin, the quality and association with such brand. This characteristic made the notion willingness to buy. In study willingness to buy has been discussed as the perception to purchase product with attributes i.e. country of origin, quality and likelihood to purchase.

\subsection{The Role of Age}

The literature provides insight about the relation of age and ethnocentrism. The researcher substantiates and found that older are more ethnocentrism (Balabanis et al. 2001; Han \& Terpstra, 1988; Sharma et al 1995). Another research which has found that young consumers are more ethnocentric than older (Bannister \& Saunders, 1978; Schooler, 1971). This issue leads us to get more insight and try to find that what is the role of age on consumer ethnocentrism is. Bannister \& Saunders (1978) found that the consumer attitudes of U.K consumers are more favorable towards their product as their age increases. They explained that the older are more ethnocentric than young. Schooler (1971) in his research found that young are more ethnocentric. It has also found that there is a significant difference of ethnocentrism among their ages.

Consumers of different continents shows that old are more ethnocentric the young respondents. (Mittal \& Tsiros, 1995) argues that young are more ethnocentric and this notion has been supported by (Bannister \& Saunders, 1978; Schooler, 1971).

Shimp \& Sharma (1987) measured ethnocentrism first time. Several studies published prior to 1987 (Bannister \& Saunders, 1978; Schooler, 1971) who empirically try to substantiate ethnocentrism. Consumer ethnocentrism based on theories showing the group membership and its influence on consumer behavior. From literature it is concluded that older have tendency to become ethnocentric and show this behavior while purchasing or consumption. The antecedents of ethnocentrism i.e. conservatism and dogmatism are highly correlated with age (Sharma et. al, 1995; Anderson \& Cunningham, 1972).

\subsection{The Role of Gender}

The role of gender in ethnocentrism is always significant. It is important to know the gender differences while purchasing products. Research shows that female are more inclined towards products which are coming from west (Schooler, 1971). Another research shows those females are willing to purchase a product which has foreign country of origin (Dornoff, 1974). The study revealed that females are more ethnocentric than male (Caruana, 1996). But another study shows the reverse point of view i.e. male are more ethnocentric than female (Bannister \& Saunders, 1978). The same notion has been substantiated that male gives more favorable 
rating than female (Shankarmahesh, 2006). Studies shows that female rate products which belong to foreign high as compare to male (Mittal \& Tsiros, 1995). This notion also considered by (Dornoff, 1974). These studies showed that females are less ethnocentric than male which could be stated that males are more ethnocentric. They favor the products which are made locally. The literature also support the notion that male are more ethnocentric than female and they willingness to purchase products which are made locally. The research indicates the characteristic of female purchase behavior due to which they are less ethnocentric. These attributes are tested and substantiated that female are more conservative (Han \& Terpstra, 1988). Another attribute i.e. collective minded has been tested and found significant in female (Triandis, Leung, Villareal \& Clark, 1985). The attribute conservatism also found significant in female and shows higher tendency than male (Sharma et. al, 1995).

\subsection{The Role of Income}

The purchasing power of customer determines his purchase intention. As income grows the purchasing behavior also changes. This notion has been tested that an increase in income has no relation with ethnocentrism. But several studies show the negative relationship between income and ethnocentric (Caruana, 1996). But several researches deny this notion and found significant relationship between income and ethnocentrism and income and willingness to buy (Tan \& Farley, 1987). This notion the income and ethnocentrism are positive relationship substantiated by (Balabanis et. al, 2001). Research shows that who have high level of living are high ethnocentric (Tan \& Farley, 1987). Another research conducted in Singapore shows that, who are living in less privileged areas had great intentions for products which are locally made and shows the behavior of ethnocentric. The same notion tested with willingness to buy. This shows that the consumers who have high income are more ethnocentric than those who have low income. Consumers who have high income are willing to purchase products which are locally made. This notion has also tested by (Balabanis et. al, 2001).

\section{METHODOLOGY}

A sample size of 250 respondents was selected working in different organization in Karachi.Out of 250 respondents 156 were male and 94 were female. A questionnaire was used as an instrument in this research and was developed after review various studies on consumer ethnocentrism and willingness to buy. Likert scale was used in structuring questions and seven choices were provided in each statement from the degree of agreement to disagreement which enabled the respondents to answer easily. Non-restricted non-probability e sampling technique was used. Two statistical techniques were used in this research to answer the research questions. To find the answer of first question Independent sample $t$ test technique was used. This technique was used because it helped in identification of dimensions/ variables of ethnocentrism and willingness to buy among three demographic variables (age, income and gender). The second question was answered by applying simple linear Regression. This technique was used to find out the impact of the ethnocentrism on willingness to buy. 


\subsection{Research Model Developed}

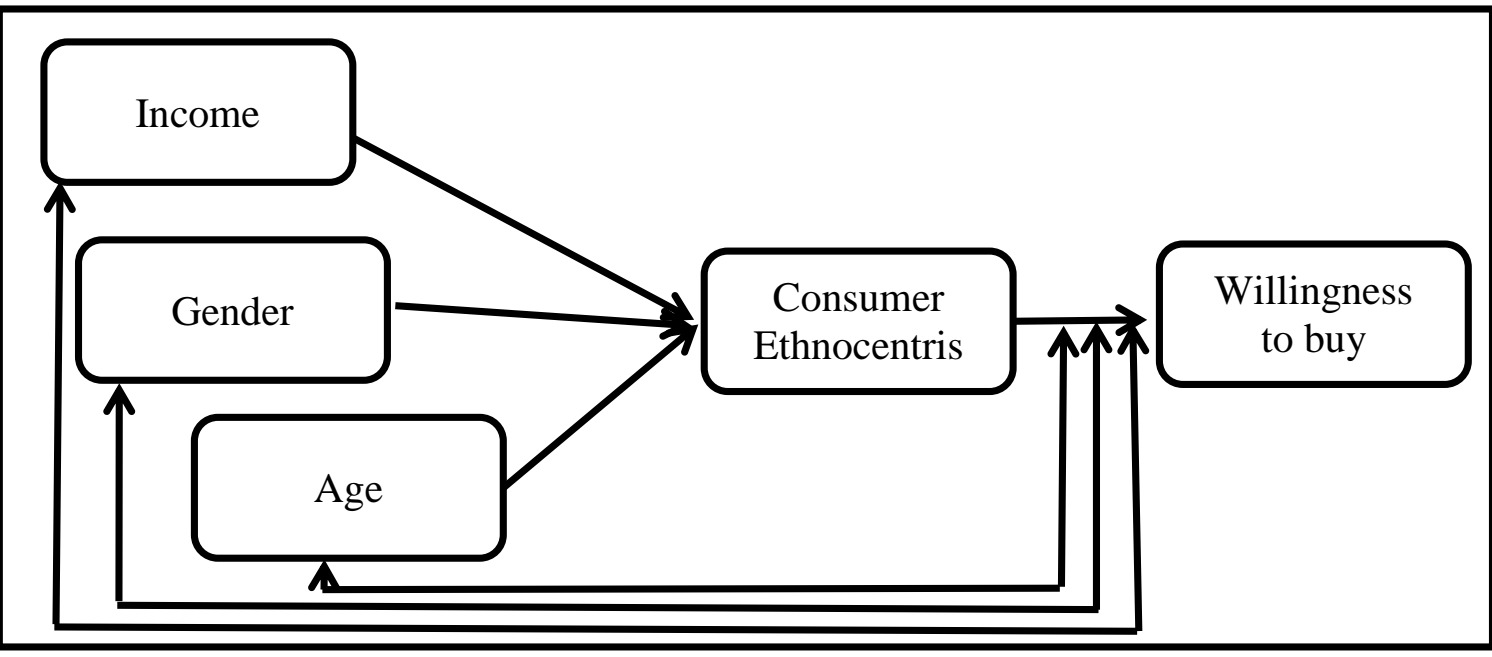

\section{RESULTS \& INTERPRETATIONS}

Table 1

Descriptive Statistics

\begin{tabular}{|c|c|c|c|c|c|c|}
\hline \multicolumn{7}{|c|}{ Mean and standard deviation of Consumer Ethnocentrism, willingness to buy and demographics } \\
\hline & \multirow{3}{*}{ Demographic } & \multirow{3}{*}{ Sample size } & \multicolumn{4}{|c|}{ Variables } \\
\hline & & & \multicolumn{2}{|c|}{ Willingness to buy } & \multicolumn{2}{|c|}{ Ethnocentrism } \\
\hline & & & Mean & S.D & Mean & S.D \\
\hline \multirow{2}{*}{ Gender } & Male & 156 & 5.113 & 1.0078 & 5.2692 & 1.04155 \\
\hline & Female & 94 & 5.5359 & .89608 & 5.7447 & .91853 \\
\hline \multirow[b]{2}{*}{ Age } & 18 to $35 \mathrm{yrs}$ & 124 & 4.9486 & .95211 & 5.05118 & 5.0118 \\
\hline & Above $35 \mathrm{yrs}$ & 126 & 5.5903 & .90852 & 5.8772 & .79479 \\
\hline \multirow[t]{2}{*}{ Income } & Below Rs 40,000 & 100 & 5.6725 & .82797 & 5.8431 & .94312 \\
\hline & Above 40,000 & 150 & 5.005 & .98923 & 5.1846 & .9892 \\
\hline
\end{tabular}

The table 1 shows descriptive statistics of the instrument for consumer ethnocentrism, willingness to buy against demographic variables with mean, standard deviation which provided the guidelines for further investigation/ testing of quality of means and variance.

Hypothesis 1: To test H1 hypothesis that Old are more ethnocentric than young, Independent sample $t$ test applied that means are equal against groups and the results were as under: 
Table 2

Group statistics

\begin{tabular}{|l|l|l|l|l|l|}
\hline Group Statistics & Age & Number & Mean & $\begin{array}{l}\text { Standard } \\
\text { Deviation }\end{array}$ & Standard. Error of Mean \\
\hline & 124 & 5.0118 & 1.04413 & .09377 & 124 \\
\cline { 2 - 6 } Ethnocentrism & 126 & 5.8773 & .79479 & .07081 & 126 \\
\hline
\end{tabular}

Table 3

Independent Sample T-Test

\begin{tabular}{|c|c|c|c|c|c|c|c|c|c|c|}
\hline \multicolumn{11}{|c|}{ Ind. samples t-test } \\
\hline & & \multicolumn{2}{|c|}{ Test of Levene } & \multicolumn{7}{|l|}{ t-test } \\
\hline & & & & & & & & & $95 \% \mathrm{C}$. & \\
\hline & & $\begin{array}{l}\text { F- } \\
\text { valu } \\
\text { e }\end{array}$ & $\begin{array}{l}\text { Significan } \\
\text { ce }\end{array}$ & t-test & $\begin{array}{l}\text { Degree } \\
\text { of } \\
\text { freedo } \\
\mathrm{m}\end{array}$ & $\begin{array}{l}\text { two-tailed } \\
\text { significan } \\
\text { ce }\end{array}$ & $\begin{array}{l}\text { Differen } \\
\text { ce of } \\
\text { Mean }\end{array}$ & SE & $\mathrm{L}$ & U \\
\hline \multirow[t]{2}{*}{$\begin{array}{l}\text { Ethnocentris } \\
\mathrm{m}\end{array}$} & $\begin{array}{l}\text { Assume } \\
\text { d EV }\end{array}$ & $\begin{array}{l}1.84 \\
2\end{array}$ & .176 & $\begin{array}{l}- \\
7.382\end{array}$ & 248 & .000 & -.86550 & $\begin{array}{l}.1172 \\
5\end{array}$ & $\begin{array}{l}- \\
1.0964 \\
3\end{array}$ & $\begin{array}{l}. \\
.63458\end{array}$ \\
\hline & $\begin{array}{l}\text { not } \\
\text { assume } \\
\text { s EV }\end{array}$ & & & -7.3 & $\begin{array}{l}229.75 \\
7\end{array}$ & .000 & -.86550 & .1175 & -1.09 & -.63 \\
\hline
\end{tabular}

The result of table 3 shows that the value for leven's test is .176 which is greater than .05 , so the case i.e. equal variance assumed is considered. In this line the $t$ value is -7.382 which is significant against .05, this shows that the means of ethnocentrism are different against young and old. In Table 2 the mean value for young is 5.0118 and for old is 5.8773, as the mean value for old is greater that young, this implies that Old are more ethnocentric than young.

Hypothesis 2: To test $\mathrm{H} 2$ hypothesis that female are more ethnocentric than male, Independent sample $t$ test applied that means are equal against groups and the results were as under:

Table 4

Group statistics

\begin{tabular}{|l|l|l|l|l|l|}
\hline \multicolumn{2}{|l|}{ Group Statistics } & \multirow{4}{*}{ Gender } & & & Standard \\
\hline \multirow{3}{*}{ Ethnocentrism } & Number & Mean & Deviation & Standard. Error of Mean \\
\cline { 2 - 7 } & Female & 156 & 5.2692 & 1.04155 & .08339 \\
\cline { 2 - 6 } & Male & 94 & 5.7447 & .91853 & .09474 \\
\hline
\end{tabular}


Table 5

Independent Sample T-Test

\begin{tabular}{|c|c|c|c|c|c|c|c|c|c|c|}
\hline \multicolumn{11}{|c|}{ Ind. samples t-test } \\
\hline & & \multicolumn{2}{|c|}{ Test of Levene } & \multicolumn{7}{|l|}{ t-test } \\
\hline & & & & & & & & & $95 \% \mathrm{C}$. & \\
\hline $\begin{array}{l}\text { Ethnocentris } \\
\mathrm{m}\end{array}$ & & $\begin{array}{l}\text { F- } \\
\text { valu } \\
\text { e }\end{array}$ & $\begin{array}{l}\text { Significan } \\
\text { ce }\end{array}$ & t-test & $\begin{array}{l}\text { Degree } \\
\text { of } \\
\text { freedo } \\
\mathrm{m}\end{array}$ & $\begin{array}{l}\text { two-tailed } \\
\text { significan } \\
\text { ce }\end{array}$ & $\begin{array}{l}\text { Differenc } \\
\mathrm{e} \quad \text { of } \\
\text { Mean }\end{array}$ & SE & $\mathrm{L}$ & $\mathrm{U}$ \\
\hline \multirow[t]{2}{*}{$\begin{array}{l}\text { Ethnocentris } \\
\mathrm{m}\end{array}$} & $\begin{array}{l}\text { Assume } \\
\text { d EV }\end{array}$ & $\begin{array}{l}1.70 \\
0\end{array}$ & .193 & $\begin{array}{l}- \\
3.652\end{array}$ & 248 & .000 & -.47545 & $\begin{array}{l}.1302 \\
0\end{array}$ & $\begin{array}{l}. \\
.73190\end{array}$ & .21900 \\
\hline & $\begin{array}{l}\text { not } \\
\text { assumes } \\
\text { EV }\end{array}$ & & & $\begin{array}{l}- \\
3.767\end{array}$ & $\begin{array}{l}215.36 \\
6\end{array}$ & .000 & -.47545 & $\begin{array}{l}.1262 \\
1\end{array}$ & $\begin{array}{l}- \\
.72422\end{array}$ & .22668 \\
\hline
\end{tabular}

The result of table 5 shows that the value for leven's test is .193 which is greater than .05 . so the case i.e. equal variance assumed is considered. In this line the $t$ value is -3.662 which is significant against .05, this shows that the means of ethnocentrism foreign brand are different against men and women group. Table 4 shows that the mean value for male is 5.2692 and for female is 5.7447, as the mean value for female is greater that male, this accept our hypothesis and implies that Women are more ethnocentric than men.

Hypothesis 3: To test $\mathrm{H} 3$ hypothesis that consumers with low income are more ethnocentric than consumer with high income, Independent sample $t$ test applied that means are equal against groups and the results were as under:

Table 6

Group statistics

\begin{tabular}{|l|l|l|l|l|l|l|}
\hline Group Statistics & \multicolumn{1}{|l|}{ Number } & Mean & $\begin{array}{l}\text { Standard } \\
\text { Deviation }\end{array}$ & $\begin{array}{l}\text { Standard. Error of } \\
\text { Mean }\end{array}$ \\
\hline & Income & Num & .94312 & .09431 \\
\hline Ethnocentrism & $\begin{array}{l}\text { Below } \\
40000\end{array}$ & 100 & 5.8431 & .94312 & .08077 \\
\cline { 2 - 7 } & $\begin{array}{l}\text { Above Rs } \\
40000\end{array}$ & 150 & 5.1846 & .98920 & \\
\hline
\end{tabular}


Table 7

Independent Sample T-Test

\begin{tabular}{|c|c|c|c|c|c|c|c|c|c|c|}
\hline \multicolumn{11}{|c|}{ Ind. samples t-test } \\
\hline & & \multicolumn{2}{|c|}{ Test of Levene } & \multicolumn{7}{|l|}{ t-test } \\
\hline & & & & & & & & & $95 \%$ & \\
\hline $\begin{array}{l}\text { Ethnocentris } \\
\mathrm{m}\end{array}$ & & $\begin{array}{l}\text { F- } \\
\text { valu } \\
\text { e }\end{array}$ & $\begin{array}{l}\text { Significanc } \\
\mathrm{e}\end{array}$ & t-test & $\begin{array}{l}\text { Degree } \\
\text { of } \\
\text { freedo } \\
\mathrm{m}\end{array}$ & $\begin{array}{l}\text { two-tailed } \\
\text { significanc } \\
\text { e }\end{array}$ & $\begin{array}{l}\text { Differenc } \\
\text { e of Mean }\end{array}$ & SE & $\mathrm{L}$ & $\mathrm{U}$ \\
\hline \multirow[t]{2}{*}{$\begin{array}{l}\text { Ethnocentris } \\
\mathrm{m}\end{array}$} & $\begin{array}{l}\text { Assume } \\
\text { d EV }\end{array}$ & .321 & .571 & $\begin{array}{l}5.25 \\
2\end{array}$ & 248 & .000 & .65846 & $\begin{array}{l}.1253 \\
6\end{array}$ & $\begin{array}{l}.4115 \\
5\end{array}$ & $\begin{array}{l}.9053 \\
8\end{array}$ \\
\hline & $\begin{array}{l}\text { not } \\
\text { assumes } \\
\text { EV }\end{array}$ & & & $\begin{array}{l}5.30 \\
3\end{array}$ & $\begin{array}{l}219.14 \\
5\end{array}$ & .000 & .65846 & $\begin{array}{l}.1241 \\
7\end{array}$ & $\begin{array}{l}.4137 \\
4\end{array}$ & $\begin{array}{l}.9031 \\
8\end{array}$ \\
\hline
\end{tabular}

The result of table 7 shows that the value for leven's test is .571 which is greater than .05 , so the case i.e. equal variance assumed is considered. In this line the $t$ value is 5.262 which is significant against .05 , this shows that the means of low income towards high income are different against ethnocentrism. In Table 6 the mean value for low income is 5.8431 and for high income is 5.1846, as the mean value for low income is greater that high income, this implies that consumers with low income are more ethnocentric than consumer with high income.

Hypothesis H4: To test $\mathrm{H} 4$ hypothesis that Old are more willing to buy locally made product than young, Independent sample t test applied that means are equal against groups and the results were as under:

Table 8: Group statistics

\begin{tabular}{|c|c|c|c|c|c|}
\hline \multicolumn{6}{|l|}{ Group Statistics } \\
\hline & Age & Number & Mean & $\begin{array}{l}\text { Standard } \\
\text { Deviation }\end{array}$ & $\begin{array}{l}\text { Standard. } \\
\text { Error of Mean }\end{array}$ \\
\hline \multirow[t]{2}{*}{ Willingness to buy } & $18-35$ & 124 & 4.9486 & .95211 & .08550 \\
\hline & Above 35 & 126 & 5.5903 & .90852 & .08094 \\
\hline
\end{tabular}


Table 9

Independent Sample T-Test

\begin{tabular}{|c|c|c|c|c|c|c|c|c|c|c|}
\hline \multicolumn{11}{|c|}{ Ind. samples t-test } \\
\hline & & \multicolumn{2}{|c|}{ Test of Levene } & \multicolumn{7}{|l|}{ t-test } \\
\hline & & & & & & & & & $95 \% \mathrm{C}$. & \\
\hline $\begin{array}{l}\text { Ethnocentris } \\
\mathrm{m}\end{array}$ & & $\begin{array}{l}\text { F- } \\
\text { valu } \\
\mathrm{e}\end{array}$ & $\begin{array}{l}\text { Significan } \\
\text { ce }\end{array}$ & t-test & $\begin{array}{l}\text { Degree } \\
\text { of } \\
\text { freedo } \\
\mathrm{m}\end{array}$ & $\begin{array}{l}\text { two-tailed } \\
\text { significan } \\
\text { ce }\end{array}$ & $\begin{array}{l}\text { Differenc } \\
\mathrm{e} \quad \text { of } \\
\text { Mean }\end{array}$ & SE & $\mathrm{L}$ & $\mathrm{U}$ \\
\hline \multirow[t]{2}{*}{$\begin{array}{l}\text { Willingness } \\
\text { to buy }\end{array}$} & $\begin{array}{l}\text { Assume } \\
\text { d EV }\end{array}$ & .076 & .782 & $-\overline{5.452}$ & 248 & .000 & -.64169 & $\begin{array}{l}.1176 \\
9\end{array}$ & -87349 & $\begin{array}{l}- \\
.40989\end{array}$ \\
\hline & $\begin{array}{l}\text { not } \\
\text { assumes } \\
\text { EV }\end{array}$ & & & $-\overline{5.450}$ & $\begin{array}{l}247.02 \\
4\end{array}$ & .000 & -.64169 & $\begin{array}{l}.1177 \\
3\end{array}$ & $\begin{array}{l}- \\
.87358\end{array}$ & $\begin{array}{l}. \\
.40980\end{array}$ \\
\hline
\end{tabular}

The result of table 9 shows that the value for leven's test is .782 which is greater than .05 , so the case i.e. equal variance assumed is considered. In this line the $t$ value is -5.452 which is significant against .05 , this shows that the means of ethnocentrism are different against young and old. Table 8 shows that the mean value for young is 4.9486 and for old is 5.5903, as the mean value for Old is greater that young, this implies that old are more willing to buy locally made product than young.

Hypothesis 5: To test H5 hypothesis that female are more willing to buy locally made product than male, Independent sample t test applied that means are equal against groups and the results were as under:

Table 10

Group statistics

\begin{tabular}{|c|c|c|c|c|c|}
\hline \multicolumn{6}{|l|}{ Group Statistics } \\
\hline \multirow{3}{*}{ Willingness to buy } & Gender & Number & Mean & $\begin{array}{l}\text { Standard } \\
\text { Deviation }\end{array}$ & Standard. Error of Mean \\
\hline & Female & 156 & 5.1130 & 1.00078 & .08013 \\
\hline & Male & 94 & 5.5359 & .89608 & .09242 \\
\hline
\end{tabular}


Table 11

Independent Sample T-Test

\begin{tabular}{|c|c|c|c|c|c|c|c|c|c|c|}
\hline \multicolumn{11}{|l|}{ Ind. samples t-test } \\
\hline & & \multicolumn{2}{|c|}{ Test of Levene } & \multicolumn{7}{|l|}{ t-test } \\
\hline & & & & & & & & & $95 \%$ & \\
\hline $\begin{array}{l}\text { Willingness to } \\
\text { buy }\end{array}$ & & $\begin{array}{l}\text { F- } \\
\text { valu } \\
\text { e }\end{array}$ & $\begin{array}{l}\text { Significan } \\
\text { ce }\end{array}$ & t-test & $\begin{array}{l}\text { Degre } \\
\mathrm{e} \text { of } \\
\text { freedo } \\
\mathrm{m}\end{array}$ & $\begin{array}{l}\text { two-tailed } \\
\text { significan } \\
\text { ce }\end{array}$ & $\begin{array}{l}\text { Differen } \\
\text { ce of } \\
\text { Mean }\end{array}$ & SE & $\mathrm{L}$ & U \\
\hline \multirow[t]{2}{*}{$\begin{array}{l}\text { Willingness to } \\
\text { buy }\end{array}$} & $\begin{array}{l}\text { Assum } \\
\text { ed EV }\end{array}$ & $\begin{array}{l}1.19 \\
2\end{array}$ & .276 & $\begin{array}{l}- \\
3.36 \\
4\end{array}$ & 248 & .001 & -.42292 & $\begin{array}{l}.1257 \\
2\end{array}$ & $\begin{array}{l}- \\
.6705 \\
4\end{array}$ & $\begin{array}{l}- \\
.1753 \\
1\end{array}$ \\
\hline & $\begin{array}{l}\text { not } \\
\text { assume } \\
\text { s EV }\end{array}$ & & & $\begin{array}{l}- \\
3.45 \\
7\end{array}$ & $\begin{array}{l}213.10 \\
4\end{array}$ & .001 & -.42292 & $\begin{array}{l}.1223 \\
2\end{array}$ & $\begin{array}{l}- \\
.6640 \\
4\end{array}$ & $\begin{array}{l}- \\
.1818 \\
1\end{array}$ \\
\hline
\end{tabular}

The result of table 11 shows that the value for leven's test is 0.276 which is greater than .05 , so the case i.e. equal variance assumed is considered. In this line the $t$ value is -3.364 which is significant against .05, this shows that the means of western life style are different against lower income group and upper income group. Table 10 shows that the mean value for men is 5.1130 and for women is 5.5359 , as the mean value for women is greater men, this implies that female are more willing to buy local product than male.

Hypothesis 6: To test H6 hypothesis that Low income consumers willing to buy locally made product than high income Independent sample $t$ test applied that means are equal against groups and the results were as under:

Table 12

Group statistics

\begin{tabular}{|l|l|l|l|l|l|l|}
\hline Group Statistics & & & & $\begin{array}{l}\text { Standard } \\
\text { Deviation }\end{array}$ & $\begin{array}{l}\text { Standard. Error of } \\
\text { Mean }\end{array}$ \\
\hline & income & Number & Mean & .82797 & .08280 \\
\hline Ethnocentrism & \begin{tabular}{ll|ll} 
Below \\
40000
\end{tabular} & 100 & 5.6725 & & \\
\cline { 2 - 7 } & $\begin{array}{l}\text { Above } \\
40000\end{array}$ & & 150 & 5.0050 & .98923 & .08077 \\
\hline
\end{tabular}


Table 13

Independent Sample T-Test

\begin{tabular}{|c|c|c|c|c|c|c|c|c|c|c|}
\hline \multicolumn{11}{|c|}{ Ind. samples t-test } \\
\hline \multirow[b]{2}{*}{$\begin{array}{l}\text { Willingness to } \\
\text { buy }\end{array}$} & & \multicolumn{2}{|c|}{ Test of Levene } & \multicolumn{7}{|l|}{ t-test } \\
\hline & & $\begin{array}{l}\text { F- } \\
\text { valu } \\
\text { e }\end{array}$ & $\begin{array}{l}\text { Significan } \\
\text { ce }\end{array}$ & $\begin{array}{l}\mathrm{t}- \\
\text { test }\end{array}$ & $\begin{array}{l}\text { Degree } \\
\text { of } \\
\text { freedo } \\
\mathrm{m}\end{array}$ & $\begin{array}{l}\text { two-tailed } \\
\text { significan } \\
\text { ce }\end{array}$ & $\begin{array}{l}\text { Differen } \\
\text { ce of } \\
\text { Mean }\end{array}$ & $\mathrm{SE}$ & $\mathrm{L}$ & $\mathrm{U}$ \\
\hline \multirow[t]{2}{*}{$\begin{array}{l}\text { Willingness to } \\
\text { buy }\end{array}$} & $\begin{array}{l}\text { Assumed } \\
\text { EV }\end{array}$ & $\begin{array}{l}2.10 \\
1\end{array}$ & .148 & $\begin{array}{l}5.57 \\
0\end{array}$ & 248 & .000 & .66750 & $\begin{array}{l}.1198 \\
3\end{array}$ & $\begin{array}{l}.4314 \\
8\end{array}$ & $\begin{array}{l}.9035 \\
2\end{array}$ \\
\hline & $\begin{array}{l}\text { not } \\
\text { assumes } \\
\text { EV }\end{array}$ & & & $\begin{array}{l}5.77 \\
1\end{array}$ & $\begin{array}{l}235.42 \\
3\end{array}$ & .000 & .66750 & $\begin{array}{l}.1156 \\
7\end{array}$ & $\begin{array}{l}.4396 \\
2\end{array}$ & $\begin{array}{l}.8953 \\
8\end{array}$ \\
\hline
\end{tabular}

The result of table 13 shows that the value for leven's test is .148 which is greater than .05 , so the case i.e. equal variance assumed is considered. In this line the $t$ value is 5.570 which is significant against .05, this shows that the means of willingness to buy are different against low income and high income. Table 12 shows that the mean value for Low income is 5.6725 and for high income is 5.0050, as the mean value for Low income is greater than high income, this implies that Low income consumers willing to buy local product than high income.

Hypothesis 7: To test $\mathrm{H} 7$ hypothesis there is significant impact of ethnocentrism on willingness to buy locally made products, simple linear Regression technique was applied and the results were as under:

\section{Table 14}

Descriptive Statistics

\begin{tabular}{|c|c|c|c|}
\hline \multicolumn{4}{|c|}{ Descriptive Statistics } \\
\hline & Mean & Std. Deviation & $\mathrm{N}$ \\
\hline Willingness to buy & 5.2720 & .98260 & 250 \\
\hline Ethnocentrism & 5.4480 & 1.02160 & 250 \\
\hline
\end{tabular}

Table 15

Correlation

\begin{tabular}{|l|l|l|l|}
\hline \multicolumn{2}{|l|}{ Correlations } & \multicolumn{2}{|l|}{} \\
\hline \multirow{3}{*}{ Pearson Correlation } & Willingness to buy & Ethnocentrism \\
& Ethnocentrism & 1.000 & .831 \\
\hline \multirow{2}{*}{ Sig. (1-tailed) } & Willingness to buy & .831 & 1.000 \\
\cline { 2 - 4 } & Ethnocentrism &. & .000 \\
\hline $\mathrm{N}$ & Willingness to buy & .000 &. \\
\cline { 2 - 4 } & Ethnocentrism & 250 & 250 \\
\hline
\end{tabular}


Table 16

Model Summary

\begin{tabular}{|c|c|c|c|c|c|c|c|c|c|}
\hline \multicolumn{10}{|c|}{ Model Summary ${ }^{b}$} \\
\hline \multirow[b]{2}{*}{ Model } & \multirow[b]{2}{*}{$\mathrm{R}$} & \multirow[b]{2}{*}{ R Square } & \multirow[b]{2}{*}{$\begin{array}{l}\text { Adjusted R } \\
\text { Square }\end{array}$} & \multirow{2}{*}{$\begin{array}{l}\text { Std. Error } \\
\text { of the } \\
\text { Estimate }\end{array}$} & \multicolumn{5}{|c|}{ Change Statistics } \\
\hline & & & & & $\begin{array}{l}\mathrm{R} \text { Square } \\
\text { Change }\end{array}$ & F Change & df1 & df 2 & $\begin{array}{l}\text { Sig. F } \\
\text { Change }\end{array}$ \\
\hline 1 & $.831^{\mathrm{a}}$ & .691 & .690 & .54696 & .691 & 555.599 & 1 & 248 & .000 \\
\hline
\end{tabular}

Table 17

Anova

\begin{tabular}{|l|l|l|l|l|l|l|}
\hline \multicolumn{2}{|l|}{ ANOVA $^{\mathbf{b}}$ Model } & $\begin{array}{l}\text { Sum } \\
\text { Squares }\end{array}$ & Df & Mean Square & F & Sig. \\
\hline 1 & Regression & 166.217 & 1 & 166.217 & 555.599 & $.000^{\text {a }}$ \\
\cline { 2 - 8 } & Residual & 74.193 & 248 & .299 & & \\
\cline { 2 - 8 } & Total & 240.410 & 249 & & & \\
\hline
\end{tabular}

Table 18

Coefficients

\begin{tabular}{|c|c|c|c|c|c|c|}
\hline \multicolumn{7}{|c|}{ Coefficients $^{\mathbf{a}}$} \\
\hline & & \multicolumn{2}{|c|}{$\begin{array}{l}\text { Unstandardized } \\
\text { Coefficients }\end{array}$} & $\begin{array}{l}\text { Standardized } \\
\text { Coefficients }\end{array}$ & \multirow[b]{2}{*}{$\mathrm{t}$} & \multirow[b]{2}{*}{ Sig. } \\
\hline \multicolumn{2}{|c|}{ Model } & B & Std. Error & Beta & & \\
\hline \multirow[t]{2}{*}{1} & (Constant) & .915 & .188 & & 4.865 & .000 \\
\hline & Ethnocentrism & .800 & .034 & .831 & 23.571 & .000 \\
\hline
\end{tabular}

a. Dependent Variable: willingness to buy

The results of table 17 shows that $F$ value is 555.599 which is significant, shows that the model is fit. The table 16 shows value of $\mathrm{R}$ square is .691 explain that 69.1 percent predictor i.e. ethnocentrism has explained the dependent variable i.e. willingness to buy and in the table 18 the value of $t$ statistics ethnocentrism is 23.571 which is significant against .05 level of significance. Further table 15 shows the value of correlation between ethnocentrism on willingness to buy which is .831 it implies that there is positive correlation. Thus hypothesis has accepted ethnocentrism has a significant impact on willingness to buy. More the ethnocentrism, more the willingness to buy locally made product will be among consumers.

\section{CONCLUSION}

This study was different from other related studies as in other studies discussed ethnocentrism with demographic but this study further explore the perception regarding willingness to buy 
locally made products and analyzed its relation with demographics. The detail was discussed under the heading of Findings \& Interpretation of the Results in previous chapter. Further this study had also supported the existing studies but under different scenario.

After completion of survey of two hundred and fifty respondents from different organizations including University, Banks, private firms and NGOs through a developed instrument (questionnaire). Independent Sample t test technique was applied to find the answer of first research question. The results were found that the ethnocentrism differ against age, income and gender. It also found that willingness to buy differ across age, gender and income. Results shows that young (18-35 years) are less ethnocentric as compare to old (above 35 years). It also reveals that young are less willingness to buy as compare to old. In gender demographic it was found that females are more ethnocentric and willing to buy locally made product than male. With demographic income it was found that high income groups are less ethnocentric and willing to buy the local products as compare to low income group. To find the answer of second research question one hypotheses was developed. Simple linear regression analysis was applied and found the significant results against .05 level of significance that there is significant impact of ethnocentrism on willing to buy local products.

\section{REFERENCES}

Anderson, W. T. \& Cunningham, W. H. (1972). Gauging foreign product promotion, Journal of Advertising Research, Vol. 12, No. 1, pp. 29-34.

Balabanis, G., Mueller, R. \& Melewar, T. C. (2002). The human values' lenses of country of origin images, International Marketing Review, Vol. 19, No. 6, pp. 582-598.

Bannister, J. P. \& Saunders, J. (1978). UK consumers' attitudes towards imports: The Measurement of National Stereotype Image, European Journal of Marketing, Vol. 12, No. 8, pp. 562-570.

Baughn, C. C. \& Yaprak, A. (1996). Economic Nationalism: Conceptual and Empirical Development, Political Psychology, Vol. 17, No. 4, pp. 759-778.

Cannon, H. M. \& Yaprak, A. (2002). Will the real world citizen please stand up! The many faces of cosmopolitan consumer behavior, Journal of International Marketing, Vol. 10, No. 4, pp. 3052.

Caruana, A. (1996). The effects of dogmatism and socla class variables on consumer ethnocentrism in Malta, Marketing Intelligence \& Planning, Vol. 14, No. 4, pp. 39-51.

Chao, P. (2005). Celebrity and foreign brand name as moderators of country-of-origin effects International Journal of Advertising, Vol. 24, No. 2, pp. 173-191.

Cooil, B. (2007). A longitudinal analysis of customer satisfaction and share of wallet: Investigating the moderating effect of customer characteristics, Journal of Marketing, Vol. 71, No. January, pp. 67-83.

Crask, M. \& Reynolds, F. (1978). An in-depth profile of the department store shopper, Journal of Retailing, Vol. 54, No. 2, pp. 23-32.

Cleveland, M., Laroche, M. \& Papadopoulos, N. (2009). Cosmopolitanism, Consumer Ethnocentrism, and Materialism: An Eight-Country Study of Antecedents and Outcomes, Journal of International Marketing, Vol. 17, No. 1, pp. 116-146.

Dornoff, R. (1974). Consumers' perceptions of imports, Akron Business and Economic Review, Vol. 5, No. Summer, pp. 26-29. 
Fisher, R. and Dubé, L. (2005). Gender differences in responses to emotional advertizing: A social desirability perspective, Journal of Consumer Research, Vol. 31, No. March, pp. 850-858.

Han, C. M. \& Terpstra, V. (1988). Country-Of-Origin Effects For Uni-National And Bi- National Products, Journal of international business studies, Vol. 19, No. 2, pp. 235- 255

Hannerz, U. (1990). Cosmopolitans and Locals in World Culture, Theory, Culture and Society, Vol. 7, No., pp. 237-251.

Keillor, B. D. \& Hult, G. T.(1999).A five-country study of national identity, International Marketing Review, Vol. 16, No. 1, pp. 65-82

Kaynak, E. \& Kara, A. (2002). Consumer perceptions of foreign products: An analysis of productcountry images and ethnocentrism, European Journal of Marketing, Vol. 36, No. 7/8, pp. 928949.

Klein, J. G., Ettenson, R. \& Morris, M. D. (1998). The animosity model of foreign product purchase: An empirical test in the People's Republic of China, Journal of Marketing, Vol. 62, No. 1, pp. 89-100.

Levine, Robert A. \& Donald T. Campbell (1972). Ethnocentrism: Theories of Conflict, Ethnic Attitudes, and Group.

Lambert-Pandraud, R., Laurant, G. \& Lapersonne, E. (2005). Repeat purchasing of new automobiles by older consumers, Journal of Marketing, Vol. 69, No. April, pp. 97- 113.

Meyers-Levy, J. \& Maheswaran, D. (1991) Exploring differences in males \& females processing strategies, Journal of Consumer Research, Vol. 18, No. June, pp. 63-70.

Mittal, V. \& Tsiros, M. (1995). Does Country of Origin Transfer Between Brands? Advances in Consumer Research, Vol. 22, No. 1, pp. 292-296.

Olsen, J. E., Granzin, K. L. \& Biswas, A. (1993). Influencing consumers' selection of domestic versus imported products: Implications for marketing based on a model of helping behavior, Journal of the Academy of Marketing Science, Vol. 21, No. 4, pp. 307-321.

Porter, M. (1990). The competitive advantage of nations, New York, Free Press.

Sumner, G. A. (1906). Folkways. New York: Ginn Custom Publishing

Steenkamp, J.-B. E. M., Hofstede, F. t. \& Wedel, M. (1999) A Cross-National Investigation into the Individual and National Cultural Antecedents of Consumer Innovativeness, Journal of Marketing, Vol. 63, No. 2, pp. 55-69.

Schooler, R. D. (1971). Bias Phenomena Attendant to the Marketing of Foreign Goods in the US, Journal of international business studies, Vol. 2, No. 1, pp. pp. 71-80.

Shankarmahesh, M. N. (2006). Consumer ethnocentrism: an integrative review of its antecedents and consequences, International Marketing Review, Vol. 23, No. 2, pp.146 - 72

Sharma, S., Shimp, T. A.\& Shin, J. (1995). Consumer ethnocentrism: A test of antecedents and moderators, Journal of the Academy of Marketing Science, Vol. 23, No. 1, pp. 26-37.

Shimp, T. A. and Sharma, S. (1987). Consumer Ethnocentrism: Construction and Validation of the CETSCALE, Journal of Marketing Research, Vol. 24, No. 3, pp. 280-289.

Tan, C. T. \& Farley, J. U. (1987). The Impact of Cultural Patterns on Cognition and intention in Singapore, Journal of Consumer Research, Vol. 13, No. 4, pp. 540-544.

Thompson, C. J.\& Tambyah, S. K. (1999). Trying to be csmopolitan, Journal of Consumer Research, Vol. 26, No. 4, pp. 214-240. 
Triandis, H. C., Leung, K., Villareal, M. J.\& Clark, F. L. (1985). Allocentric versus idiocentric tendencies: Convergent and discriminant validation, Journal of Research in Personality, Vol. 19, No., pp. 395-415.

Worchel, Stephen \& Joe Cooper (1979), Understanding Social Psychology. Homewood, IL: The Dorsey Press. 